\section{Regards sur l'économie allemande}

Bulletin économique du CIRAC

$94 \mid 2009$

Varia

\title{
Communication de crise
}

HOLZINGER Stephan, WOLFF Uwe, Im Namen der Öffentlichkeit Litigation-PR als strategisches Instrument bei juristischen Auseinandersetzungen

\section{(2) OpenEdition}

1 Journals

Édition électronique

URL : http://journals.openedition.org/rea/3978

DOI : 10.4000/rea.3978

ISBN : 978-2-8218-0884-3

ISSN : 1965-0787

Éditeur

CIRAC

Édition imprimée

Date de publication : 1 décembre 2009

ISSN : 1156-8992

Référence électronique

"Communication de crise », Regards sur l'économie allemande [En ligne], 94 | décembre 2009, mis en ligne le 31 décembre 2009, consulté le 22 septembre 2020. URL : http://journals.openedition.org/rea/ 3978 ; DOl : https://doi.org/10.4000/rea.3978

Ce document a été généré automatiquement le 22 septembre 2020.

(c) CIRAC 


\section{Communication de crise}

HOLZINGER Stephan, WOLFF Uwe, Im Namen der Öffentlichkeit Litigation-PR als strategisches Instrument bei juristischen Auseinandersetzungen

\section{RÉFÉRENCE}

HOLZINGER Stephan, WOLFF Uwe, Im Namen der Öffentlichkeit - Litigation-PR als strategisches Instrument bei juristischen Auseinandersetzungen, Gabler, Wiesbaden, 2009, 260 p.

1 «Affaires» Daimler, Siemens ou Deutsche Telekom... En raison de la couverture médiatique croissante des procès économiques, la communication de crise appliquée aux contentieux juridiques prend une importance nouvelle. Car il s'agit de rallier à sa cause l'opinion publique, ce que les groupes américains ont compris depuis bien longtemps. Deux spécialistes allemands du droit de la communication ayant travaillé à l'étranger expliquent ici les domaines d'application et la portée de la communication de crise en cas de procès, donnant la parole à des juges, avocats et professeurs de droit sous forme d'interviews. (sh) 